\title{
Biologists seek to revamp biowarfare register
}

Helen Pearson, New York

A rebellion is brewing among US scientists who handle pathogens that could be used in biological warfare. The official list of hazardous bacteria, viruses and toxins is so frustrating to some microbiologists that they are trying to rationalize it.

The 'select agents' list, drafted by the US Centers for Disease Control and Prevention (CDC) in Atlanta, Georgia, details some 40 microbes and toxins that could threaten public health if they escaped or fell into the wrong hands. Labs that work with them must follow strict security measures. But some researchers are unhappy with the register, pointing out that relatively innocuous pathogens, such as the fungus Coccidioides immitis, are placed under the same tight restrictions as lethal viruses such as smallpox. "The list is very arbitrary," says microbiologist Arturo Casadevall of the Albert Einstein College of Medicine in New York.

Critics say that the list was drafted in haste after the 2001 anthrax mail attacks, without sufficient consultation with the scientific community. They say it relies too heavily on whether agents have been used as biological weapons in the past, rather than their potential for use in the future.

Now Casadevall and his colleague Liiseanne Pirofski have suggested a way to redo the list by calculating the biological-weapon potential of each microbe (Trends Microbiol. 12,259-263; 2004). Their formula considers a pathogen's virulence, ability to jump from person to person, incubation period and capacity to remain in the environment. The

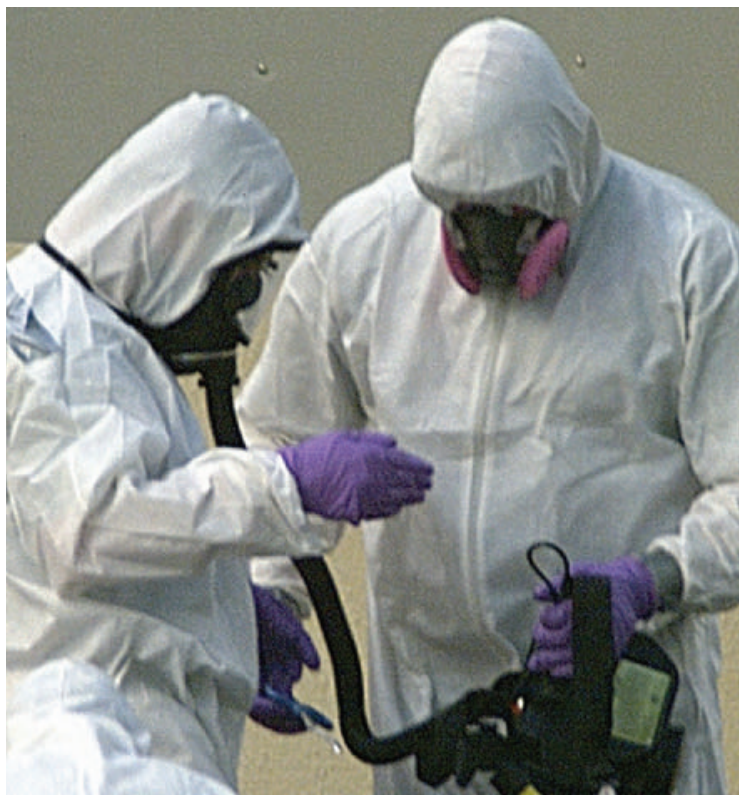

Fears of a biological attack have led to strict research controls.

CDC's list takes similar factors into account, but not in a quantitative fashion.

The new system could be used to partition microbes into categories reflecting different levels of threat. At the moment, "you're either on the list or you're off it", says Reynolds Salerno of Sandia National Laboratories in Albuquerque, New Mexico. It could also be used to work out whether emerging infectious diseases should be added. The virus responsible for severe acute respiratory syndrome (SARS), for example, which is not on the list, comes out with a weapon potential above that of anthrax and below that of smallpox.

"The formula is a good attempt to bring order to the process," says Ian Lipkin, an expert on infectious diseases and biodefence at Columbia University in New York.

As yet, there is no agreement on the precise formula that should be used. Salerno is working on his own formula, which factors in how easily a dangerous strain might be obtained by bioterrorists and the simplicity with which it could be converted into a bioweapon.

Many researchers have mixed feelings about seeing their favourite organism labelled a select agent. On the one hand, they fret about strict security requirements that can hamper their research. On the other, such a listing can help bring in cash, as a separate but overlapping list is used by the National Institute of Allergy and Infectious Diseases (NIAID) in Bethesda, Maryland, to allocate biodefence-research funds.

The existence of such similar, overlapping lists further frustrates researchers. The lists are often confused with each other, says Casadevall — he admits that even the published version of his paper managed to mix up two of the lists without the reviewers or the journal noticing.

The CDC should recruit a panel of experts from the scientific community to resolve these issues, says Janet Shoemaker, head of public affairs at the American Society for Microbiology, who has worked closely with the government over the regulation of biological agents.

For the moment, the CDC says that it has no plans to revise its select-agent list. The NIAID says it plans to talk with other government agencies about possibly using a formula to bring at least some of the various lists into line with each other.

\section{Budget delays threaten to leave US science in limbo}

\section{Geoff Brumfiel}

While researchers relax for the summer holidays, science lobbyists in Washington are feeling tense about the state of the US budget.

For the third straight year, the budget looks as though it will be severely delayed raising concern that research may be stymied in the months to come.

As Nature went to press, Congress had failed to complete work on any of the 13 spending bills that provide funding for the US government in fiscal year 2005, which begins on 1 October 2004. Squabbling over the overall budget has held up work on the bills.

With the Congress summer recess set to begin on 23 July, this situation seems unlikely to change much. Experts say little will probably be done until after the
November presidential election. Many think that any shift in power will make it difficult to resolve the budget bills before the newly elected members of government take over in January. "I can't imagine we will be done until February or March," says one staffer at the House of Representatives.

That could mean trouble for science funding, according to Janet Shoemaker, head of public affairs at the American Society for Microbiology in Washington. If the budgets aren't passed on time, Congress will pass a series of 'continuing resolutions' that will supply funding at 2004 levels. Until a budget is passed, agencies will be unable to fund new projects set to begin in 2005 , Shoemaker says. Although most agencies anticipate a few months' delay each year, the potential for a prolonged hold-up is worrying. "Beyond January it becomes a severe problem," she says.

That was the case after the mid-term election in 2002, when the government ran on continuing resolutions for nearly five months before finally approving a budget in February (see Nature 421, 774; 2003).

Work done on the budget so far indicates that science agencies are unlikely to get much in the way of new funds even when the spending bills do pass. A report last week from the House subcommittee working on the budget for the National Institutes of Health indicated that the agency could receive an increase of $\$ 727$ million for 2005 - a $2.6 \%$ rise from its current funding level of $\$ 28.5$ billion. 